\title{
Failure of Public Administration in Nigeria
}

\author{
Inuwa Abdu Ibrahim \\ Department of Public Administration Federal Polytechnic, Bauchi
}

\begin{abstract}
The research looks at the country called Nigeria, the period of independence from 1960 to the present day, over five decades sovereignty. The latent leaders, poor management styles and the present deteriorating state of affairs in Nigeria. The paper thus, looks at Nigeria-past, present and possible future implications, using secondary sources of data. In conclusion, the research affirms constitutional review and participation as the true solutions to the deteriorating and paralyzing conditions in Nigeria as it affects public Administration.
\end{abstract}

Keywords: Nigeria, Public Administration, corruption, crises, constitution

\section{Introduction}

On the $1^{\text {st }}$ of October 1960, Nigeria achieved independence with the promise of a better Nigeria. The independence constitution has the Prime Minister as Head of Government with the Queen of England as the ceremonial head of state. The republican constitution of 1963 remove the last visible hold on power by the colonial masters, by changing the queen and replacing her with the office of the president (Ceremonial Head of State) under a parliamentary government. In a democratic environment, the state operates to ensure the general welfare of its people. Therefore, the state is a natural design for promoting social good and public welfare (Okoli, 1990). The government of the newly independent Nigeria where however unable to truly unite and see beyond their ethnic differences and regional interests.

The census crisis of 1962/63 treaty to bring the end of the Nigerian state due to alleged mass rigging to inflate census figures for the purpose of attaining increased revenue allocation. Perhaps (Anyaele, 2003) sums it best when he states that:

The situation was saved by the timely intervention of the Prime Minister, Sir Abubakar who promised to take up the matter with the regional premiers. When the prime minister and regional premiers met on February 19, 1963, they agreed that the 1962 census figures be nullified and fresh one be held toward the end of 1963.

As a result, a census board was set up to conduct another census. A new census was conducted in November 1963 and in February 1964 the provisional figures that put the population of Nigeria at 55.7 million were published. A breakdown of the figures gave the North 29.8 million, East 12.4 million, west 10.3 million, Midwest 2.5 million and Lagos 0.7 million. The eastern and mid-western regional governments rejected the figures but were accepted by the Northern and western regional governments....

Other major crisis that steered the leaders away from the struggles for development, sustained peace and unity include the action group crisis of 1962, which was an intra-party crisis in the western region. The electoral crisis of 1964 (Federal elections) and the western Nigeria elections of 1965 which were characterized by intimidation, rigging, thuggery and violence.

Major General Aguiyi Ironsi took over power as the first military head of state after a bloody coup on January 15,1966 . His regime replaced the federal system with the unitary system of government. The overthrow of the Ironsi regime on the $29^{\text {th }}$ of July, 1966 ushered in the then Lt. Col Yakubu Gowon. The Gowon military government created 12 states out of the country, thereby remaining the regional system. This act was the straw that broke the camels back, three days later (30/05/1967) Odumegwu Ojukwu declared the Eastern region as the Independent State of Biafra. "The civil was that followed which ended in January, 1970, threatened the corporate existence of Nigerian Federalism" (Anyaele, 2013).

General Murtala Mohammed took over power in July 1975 after a bloodless coup. In February 3, 1976 the military government increased the number of states to 19. After the death of Murtala during an abortive coupon $13^{\text {th }}$ of February 1976 Gen. Obasanjo continued as Head of State and Commander in Chief. The regime handed over power an elected civilian government in 1979.

The Second Republic of President Shehu Shagari took over using the presidential system of government. Even though the government was not characterized by monumental ethnic tensions as was prevalent during the first republic, it was however vividly showing signs of high level corruption and indiscipline among other latent tendencies. 
General Buhari took over power from Shagari after widely rigged elections on the $31^{\text {st }}$ of December, 1983. The regime lasted only 20 months.

General Babangida Ibrahim carried out a coup on $27^{\text {th }}$ of August 1985, which overthrow the regime of Muhammadu Buhari. He increased the number of states from nineteen to thirty.

Gen. Sani Abacha took the stage after a palace coup that took over power from Babangida appointed interim National Government led by Chief Ernest Shonekan on the $17^{\text {th }}$ of November 1993. Abacha created six additional states making a total of 36 states. Upon the death of Abacha in June 8, 1998 Gen. Abdulsalami Abubakar assumed the seat of head of State.

Gen Abdulsalami ruled from June, 1998 to May, 1999 when he successfully handed over power to democratically elected government. Since May $29^{\text {th }} 1999$ Nigeria has been under democratic governance, yet the state is at its lowest, in comparison to the past democratic dispensation. This could be linked to the Masterservant relationship and attitude of the leaders which (Parsons, 1960) terms latent functions.

\section{Public Administration, Corruption, Crises and the Constitution}

Public Administration has been relevant in the world since the period of social contracts. Thomas Hobbes $(1588$ - 1679) a social contract theorist describes the need for government (public administration) as a necessity if we are to avoid a state of nature, where life would be "solitary", brutish, nasty, poor and short due to absence of government to regulate public life, anarchy would prevail.

Administration is a process of organizing, directing the human and material resources towards the attainment of organizational goals. It must exist in any organization for a defined objectives because each one consists of human beings brought together in a hierarchical set up, making use of tools, equipment, both human and material resources, all with an effort to achieve the objectives for which the organization is established (Adebayo, 1992).

When qualified with the word "public" it refers to administration by government and its agents (Dimock, 1956) sees public administration as concerned with what and how of government.

The military to civilian handover on the $29^{\text {th }}$ of May, 1999 came with it similar euphoric expectations at independence $1^{\text {st }}$ October, 1960. But alas just like the first republic the widely accepted and popularly voted government of Olusegun Obasanjo ended its tenure without living up to its promises and potential (Dowden, 2008) puts it this way:

With the legacy of sixteen years of bad military rule, strong international support and a six fold increase in Nigeria's oil revenue during Obasanjo's eight years as president, it is hard to find exactly how he managed to end his reign as just about the most unpopular man in Nigeria. When he came to power, he had all the cards. He could have bought off or charmed opponents, taken steps such as providing electricity and clean water. He could have left a legacy of real change, a transformed Nigeria, but Obasanjo left office discredited and disgraced.

Yar'adua spent the better part of his tenure treating his deteriorating health. Upon his death his vice, Jonathan Goodluck took over as the new president. Every sector of our national lives has either been ruined by governments actions and or inaction or its potentials never been fully tapped. Leaders are more concerned with what matters to them and not what matters to the Nigerian State.

\section{Politics}

The Nigerian political scene today is full of political tension, maneuvering and even intimidation (DailyTrust, 2013) reports of an uncovered plot by the presidency to arrest former President Olusegun Obasanjo and former Vice President Atiku Abubakar for identifying with the new PDP. This builds into their plans to deal with the group of seven governors (G-7) and their supporters. The paper reports that in a press statement the National Publicity Secretary of the Party Eze Chukwuemeka Eze made the allegation, which he puts this way: The sin of these two distinguished Nigerian statemen (Obasanjo and Atiku) according to those plotting their 'demystification' is their alleged support for the new PDP, including the G7 governors. That those evil plots are being conceived by the presidency confirms that the Abacha days are truly here again with us.

The fight for a second term it seems has diverted the attention of all but the masses from what really matters.

\section{Security}

The continued state of insecurity continues unabated, with the killings in September, 2013 of 21 students of the College of Agriculture in Yobe State, and the killing of at least fifteen people in the same month (September) in fresh violence between the Agatu people from Benue State and the Fulani cattle breeders. Whether political, religious or ethnic, one is clear Nigeria is in a state of insecurity with many skeptical as to the governments' political will to truly tackle insecurity in the country. 


\section{Health}

The health sector is no better, with resident doctors currently (17/102013) on an industrial action with the effects of brain drain and inadequate medical equipments. We can now add the absence of medical doctors to the list. (DailyTrust, 2013) reports that the Minister of Health O. Chukwu admitted "We understand some of the issues have not been resolved...."

\section{Education}

Nigeria is characterized by recurrent and lingering strikes by academics and non academics at different levels of the education system. The current Academic Staff Union of Universities (ASUU) strike is an example of how much education and human capital have been neglected (Jideofor, 2013) sums it up:

That the Nigerian education system is in severe crisis is self evident. If the increasing trend of our university graduates being unable to read and write is not enough evidence, then the virtual absence of our universities in upper of the league of African Unities should suffice. And if you are still not convinced, you can read the articulation of the Academic Staff Union of Universities (ASUU) during its annual strikes.

Most public schools and institutions of higher learning are characterized by dilapidated structures, overcrowding in classes, poor salaries and working conditions.

\section{Others}

Virtually all sectors of public life and administration are affected by growing instability and uncertainty. The aviation arena, where Nigerians are afraid to patronize the industry with government slap on the wrist type of regulatory action in the aviation sector, annual plane crash is becoming the new trend.

All these seem like Childs' play when compared to the amount of public funds stolen by governors and other government officials since May, 1999. One would think that this is because the people have been provided the essentials by their government. This is far from the truth. The power sector is down, in fact government in the process of transferring ownership of Power Holding Company of Nigeria (PHCN) fully to private hands.

Water availability of adequate clean water supply continues to elude the authorities, with the ever booming sachet water (pure water) business springing up everywhere.

\section{Conclusion}

The long and short of it is, Nigeria as a state is sadly moving back to the state of nature. Where anarchy prevails. This is evident from the research; Nigerians are now left to basically cater for their needs.

Proliferation of various security outfits and vigilante groups offering security for a price. What I refer to as the commercialization of security in Nigeria. Those who cannot afford them are left to the mercy of thugs and robbers.

Most public hospitals cannot meet the growing medical needs of the people. People are left at the mercy of private hospitals and clinics with sometimes half-baked personnel.

In Nigeria tertiary education has no specific graduation year. The few that can afford it take their children and wards to private institutions, while the greater majority.

Democracy in Nigeria can be concluded as being the instrument of leaders, for the leaders and by the leaders. Attach a peaceful community and government would turn a blind eye but, attach the political ambition of the government in power and government will do enough to put you down.

It is becoming more and more apparent that life in Nigeria is literarily survival of the fittest. Influence and affluence remain key to power and dire sanity. According to (Macrae and Pott, 1980) each organization (and even states), must meet the challenges of its particular environment. Similarly, Buhari (1999) observes that over the years Nigeria has established the dubious reputation as a place where nothing ever gets done until money changes hands, as a result of which it has become the country with one of the highest costs of contracts in the world.

In conclusion therefore, the research has assessed the Nigerian state, from attainment of independence to the present dispensation $(1960-2013)$. The present realities and their possible implication on the future of our country. Having appreciated these realities it is important to give recommendations.

\section{Recommendations}

First and foremost it is pertinent to note that, government actions and or inaction requires legal backing. The best way to ensure the proper administration of the country is by first ensuring constitutional backing. One area where I feel a constitutional review is lacking yet badly needed is in the matter of participation.

Participation could be achieved through a constitutional review which would give more of direct democracy type powers to the people instead of the current emphasis on indirect democracy. Through awakening the "recall" section of the Nigerian Constitution and empowering the people. Considering the agitation of people and looking at the virtual non-practical application of the "recall" provisions of the constitution screams the 
need for a more constituency friendly recall constitutional law. This will have the positive effect of encouraging participation in the polity by giving back the people their delegated power.

Constitutional review in relation to ensuring accountability and financial prudence, members of both the national and state assemblies should be paid on part-time basis like is found in Switzerland. In Switzerland the law makers have jobs and other undertakings that sustain them, they go to the parliament when the need arises and are pair token allowances. This has the potential of reducing significantly the huge financial burden of maintaining a full time legislature.

Again, it brings back the representatives closer to their constituency.

Other features of the constitution that should be made more pronounce includes the referendum and the private member bills. Since leaders are seemingly incapable of doing the needful, perhaps they would be ready to serve when power is shared with the people as a means of check and balance.

\section{Reference}

[1]. Adebayo, A. (1992). Principles and Practice of Public Administration in Nigeria. Ibadan: Spectrum Books.

[2]. Anyaele, J. (2003). Comprehensive Government. Lagos: A. Johnson.

[3]. Buhari, M. (1999). Leadership and Accountability in a Period of Moral Crisis in (Eds) Mahadi, A. Kwanashie G. Leadership Accountability and the Future of Nigeria, Kaduna: Arewa House.

[4]. $\quad$ DailyTrust (2013, September 30). Presidency Plots Obasanjo, Atiku arrest- New PDP. Daily Trust , p. 3.

[5]. DailyTrust (2013, October 8). Doctors fail to end strike. Daily Trust, Newspaper, p. 4.

[6]. Dimock, M. (1956). The Executive in Action. New York: Harper and Bros.

[7]. Dowden, R. (2008). Africa: Altered States, Ordinary Miracles. London: Portobello Books.

[8]. Hobbes, T. Leviathan, Every Man Library Dent. Quoted in Appadorai, A. (1968) The Substance of Politics. London: Oxford University Press.

[9]. Jideofor, A. (2013, August 22). ASUU, Government, and Dialoguing with the deaf. DailyTrust , p. 64.

[10]. Kaufmann, Bruno et al. (eds), Guide to Direct Democracy in Switzerland and Beyond. (Amsterdam: IRI Europe, 2005 and 2008).

[11]. Macrae, S. and Pott, D. (1980). Public Administration: An Introduction. London: Pittman.

[12]. Okoli, E. A. (1990). Foundations of Governments and Politics . Onitsha: Africana-Fep.

[13]. Parsons, T. (1960). Structure and Process of Modern Society. Glencoe: Free Press.

[14]. The Nigeria Federal Government (1999). Constitution of the Federal Republic of Nigeria. Abuja: Federal Government 